\title{
Supervision and Teachers' Work Performances in Primary Schools in Konye Sub-Division in Cameroon
}

\author{
Ngemunang Agnes Ngale Lyonga \\ Department of Science of Education, \\ Higher Technical Teachers' Training College (HTTTC), \\ University of Buea, Cameroon
}

Doi: 10.2478/jesr-2018-0022

\begin{abstract}
This study examined the impact of head teachers' instructional supervision practices on teachers' performances in selected primary schools in Konye Sub-Division in Cameroon. The study used a descriptive survey design to explain the impact of head teachers' classrooms visits and checking of teaching log-books (records) on teachers' job performances. The sample size was made up of six head teachers and twenty-eight teachers selected from six schools from Konye Sub-Division, which included two state own, two confessional, and two lay private schools. A five section questionnaire was developed to collect data on head teachers' and teachers. The questionnaire was administered during one of the researcher's contact visits at the institutions. The researcher explained to the respondents who filled out the information on the questionnaire and returned after completion. The data was analyzed using SPSS version 20.0 for descriptive statistics that included the use of frequencies and percentages. Findings among others revealed the aspects that influence teachers' performances during instructional supervision by head teachers was not only classroom visits but also observation of teaching (82\% and $83.3 \%)$, examination of teaching and learning methods used by teachers during supervision (71.4\% and $66.6 \%)$, regularly checking of records of work covered by teachers (92.9\% and $83.3 \%)$, regularly checking and correcting of teachers' lesson plans (89.3\% and 100\%), and holding sessions with teachers to guide on how to improve teaching and learning activities in primary schools.
\end{abstract}

Keywords: Supervision of Instruction, Head Teachers, Teachers' Work Performances, Basic Education

\section{Introduction}

Instructional supervision of schools in Cameroon started as far back as1907, a period during which most schools where owned by the missions. Since education in Cameroon witnessed increase attention in the mid-1990s (Fonkeng, 2010), so too are supervision practices. A key theme running through the reports of both the National Education Forum (MINEDUC, 1995) and the Draft Document of the Sector-Wide Approach to Education (Republic of Cameroon, 2005) is the need to strengthen teacher quality as part of a comprehensive strategy towards efforts aimed at improving the quality of educational services at the basic level. One of the strategies adopted by the government to improve and guarantee teacher quality is the appointment of Regional Pedagogic Inspectors (RPIs) for effective supervision in the basic education ministry.

The Ministry of Basic Education within the framework of its 2012 Road Map for the purpose of quality education for all children of school-going age and in order to meet up with the vision of an "Emerging Cameroon in 2035" emphasized on the function of instructional supervision at each level in basic education. In this regard supervisors are required to carry out instructional supervision in order to improve on teachers' output; at the central, regional, divisional, and sub-divisional levels. 
Supervision of instruction is an important activity in promoting effective teaching and learning in schools. It is focused towards the improvement of instruction and professional development of teachers (Acheson, 1987). One of the major functions of a head teacher is supervision of instruction. According to Sullivan and Glanz (2000a, 2000b) the inadequate supervision of instruction by head teachers causes a lot of laxity amongst teachers in their work environment. Such laxity among teachers most often results to poor performances from pupils during examinations which might lead to the development of low self-esteem and they might end up as school dropouts at a very early stage in schooling. It is against this backdrop that this research sought to examine the influence of head teachers' instructional supervision practices on teachers' performances in Konye sub-division; a sub-division that have registered relatively high rates of failure in national basic examinations - the Cameroon Government Common Entrance and First School Leaving Certificate Examinations (Meme Regional Delegation of Education, 2016).

\section{Literature Review}

\subsection{The Concept of Supervision in Education}

Supervision in education, according to some researchers (Mohanty, 2008; Marecho, 2012; Panigrahi, 2012; Thakral, 2015) still carries the same old meaning and general concept as in Douglass and Bent's (1953) definition which means "to oversee, to superintend or to guide and to stimulate the activities of others, with a view of their improvement". The concept can be applied to either academic and administrative functions (Mohanty, 2008) of school heads, school administrators, educational administrators, or those who manage education at various levels or sectors. In a school setting, there are consisting differences between the academic and administrative functions of supervision. Whereas the academic aims of supervision include tasks such as: monitoring of instruction, guiding teachers to improve the teaching and learning process, assessment of students' learning outcomes, evaluating goals of programs, and many others, the administrative goals of supervision aimed at proper management of the school facilities and resources (Thakral, 2015).

Researchers (Wiles \& Bondi, 1996; Glickman, Gordon, \& Ross, 1998; Sergiovanni \& Starratt, 2002; Zepeda, 2007, etc) have redefined supervision as that dimension or phase of educational administration which is concerned in improving effectiveness. Supervision in education is regarded as a service to teachers and learners both as individuals and groups. It is regarded as a means of offering specialized help in improving instruction. Thus, since the main aims of supervision of instruction are to provide best practices in the teaching-learning process, to control and improve quality of learning by increasing academic achievement of learners, it is important to note that feedback from instructional supervision practices is used to help teachers obtain and apply modern teaching methods, innovations and technology in and out of their classrooms. Moreover, feedback from instructional supervision practices would also help teachers improve their work performances and enhance their professional growth and career development (Tshabalala, 2013; Wambui, 2015).

The evolution of supervision of instruction from the American "inspection and control model to humanistic and collegial model" (Moswela, 2010) has brought about the changing concept of supervision. According to Thakral (2015), this changing history of supervision is characterized by seven models: Inspection, social efficiency, democratic, scientific, leadership, and clinical supervision which constitute the "history of instructional supervision" or the "history of school supervision". Whatever the model involved, it is important that supervision of instruction accomplished instructional tasks that were set-up to be accomplished and also help provide concrete/tangible feedback to teachers on how to incorporate those instructional tasks in their teaching-learning methods for quality education. Therefore, instructional supervisors must be familiar with aspects of effective teaching and learning in school systems and the procedures for improvement (Acheson, 1987; Frazer, 2001; Gerumi, 2003; Archibong, 2012). The supervisor should also be able to detect the absence of such effective teaching and learning behaviors in schools for improvement of student learning outcomes and quality assurance in education. Thus, the role of instructional supervision in academic achievement and student success cannot be 
overlooked (Musungu \& Nasongo, 2008).

However, educational administrators (including head teachers at the level of primary education) as supervisors are also charged with pedagogic, administrative, social, financial, and functions of schools (Acheson, 1987; Mbua 2003). Not only do (instructional) supervisors correct, direct, and assist teachers in the teaching and learning process in schools in order to improve student learning and success rates, they are also expected to promote teachers' professional growth and career enhancement through supervisory duties (Tshabalala, 2013). As it is found in the literature, the rationale for instructional supervision is to ensure quality in education and to promote teachers' professional growth which in returns yields higher academic achievements and increase success rates of learners with competencies and skills (Blasé \& Blasé, 1999; Sergiovanni \& Starratt, 2002; Sullivan \& Glanz, 2000; Mohammed, 2014).

The ultimate aim of educational supervision is to improve on instruction in order to provide quality and better education (Nolan, 2004). In supervision, the supervisor need to seek the buy-in, cooperation, and collaboration of those being supervised. Such cooperation is aimed at assisting supervisors in becoming successful in performing their supervisory tasks. Supervision involve the practice of monitoring work performances of teachers and providing feedback by using benefiting and suitable strategies that enable correction of weaknesses in classroom practices in order to encourage professional growth and better the flow of quality educational activities and services. School supervision is therefore a necessary process which entails a combination of activities concerning the teaching and learning process of a school for the improvement of teaching-learning quality in a school system (Habimana, 2008; Gongera, 2013).

Wiles and Bondi (2002) mentioned that supervision as a process is facilitated by leadership through which teachers get help in counseling, planning, and talking with each other about how to improve the teaching-learning situation in school. It entails leadership, communication, curriculum development, capital development and a dynamic cooperative enterprise between instructional supervisors and teachers. Therefore for many educators, the purpose of supervision in education is to improve teaching-learning activities in schools known as "supervision of instruction" (Mohanty, 2008; Thakral, 2015). Though other necessary and important goals of supervision maybe to help teachers improve in their work performances and also for providing vital ethical, career enhancement, and professional leadership (Southworth, 2002; Nolan \& Hoover, 2004; Zepeda, 2007), the primary goal of supervision of instruction is to instigate best practices in the teachinglearning process in order to increase the learning outcomes of students through high academic achievements and high success rates. Therefore, the importance and significance of supervision in education and in teachers' work performances and professional growth cannot be overlooked as indicated in the literature (Blasé \& Blasé, 1998; Sullivan \& Glanz, 2000; Sergiovanni \& Starratt, 2002; Glatthorn, 2007; Tshabalala, 2013).

The principles of supervision indicates very clearly that schools cannot function effectively as learning organizations when teachers are unable to realize their key role and full potentials in the teaching-learning process and also effective teaching-learning may not occur if adequate and regular supervision is lacking. Thus, supervision helps in assessing the school not only in the dimension of improving instruction but also in identifying some of the school's most urgent needs for quality control and assurance in classroom practices_(Mgbodille, 1996; Sergiovani \& Starratt, 2002; Wambui, 2015). Apart from quality assurance in classroom practices, effective supervision also provides a guide for teacher's career and professional development. By assessing teachers' work performances through supervision, teachers' become aware of their weaknesses and strengths and seek ways of self-improvement based on tangible criteria and constructive feedback mechanism provided by supervision practices. Supervision practices need to provide immediate feedback and tangible ways on how to assist a teacher perform better in the teaching-learning process and support his/her professional development. At such, effective supervision therefore helps teachers to improve in their work performances, develop the ability and confidence they need in classroom practices, ensure professional growth and teacher quality. 


\subsection{Purpose of Study}

The purpose of this study was to examine the impact of head teacher's instructional supervision practices on teacher's performances in Konye Sub-Division. Pertaining to head teachers' instructional supervision practices, the study was limited to the following supervision practices: classroom visitations and checking of records; which are important aspects for helping teachers make use of feedback in order to enhance teaching/learning and professional growth.

\subsection{Study Context and Selection of Schools}

Konye Sub-Division is found in Meme Division in the South West Region of Cameroon. The SubDivision has a total of 61 primary schools and 143 teachers (Department of Statistics and School Map, Meme Divisional Delegation of Basic Education, 2016). These schools are divided into four educational zones for the purpose of this study. Out of the four educational zones, two were purposely selected for the study due to accessibility to these educational zones (Ikiliwindi and Konye central educational zones).

Out of a total number of 61 primary schools in Konye Sub-Division, six schools were selected from Konye Sub-Division, which included: Two state own, two confessional and two lay private schools. The schools were: G.S Ikiliwindi and G.S Konye for public schools; C.S Ikiliwindi and FUGOPANS Konye for confessional schools; and Standard Bilingual Konye and Lydia Bilingual Diongo for lay-private primary schools in Ikiliwindi and Konye central educational zones.

Table 1: General characteristics of participating schools

\begin{tabular}{lllcc}
\hline $\begin{array}{l}\text { Educational } \\
\text { zones }\end{array}$ & $\begin{array}{l}\text { Type of } \\
\text { school }\end{array}$ & $\begin{array}{l}\text { Name of } \\
\text { school }\end{array}$ & $\begin{array}{c}\text { Number of } \\
\text { teachers }\end{array}$ & $\begin{array}{c}\text { Number of } \\
\text { head teachers }\end{array}$ \\
\hline Ikiliwindi & Public & G.S Ikiliwindi & 05 & 01 \\
Konye & & G.S Konye & 05 & 01 \\
Ikiliwindi & Confessional & C.S Ikiliwindi & 06 & 01 \\
Konye & & FUGOPANS Konye & 06 & 01 \\
Ikiliwindi Zone & Lay private & Lydia Diongo & 03 & 01 \\
Konye Central & & Standard Konye & 04 & 01 \\
\hline & Total & & $\mathbf{2 8}$ & $\mathbf{0 6}$
\end{tabular}

Source: Divisional Delegation of Basic Education Meme - 2016/2017 Academic Year

The sample size was made up of 06 head teachers and 28 teachers selected from six schools from both Ikiliwindi and Konye educational zones. These include: G.S Konye, C.S Ikiliwindi, FUGOPANS Konye, Standard Bilingual School Konye, Lydia Bilingual Diongo and G.S Ikiliwindi as shown on Table 1. All the teachers and Head Teachers in the schools were purposely chosen in order to have a comprehensive overview of their opinions regarding the influence of head teachers' instructional supervision practices on the teachers 'performances (teaching/learning process in their work environment) in Konye Sub-Division.

\section{Research Methodology}

\subsection{Data Collection Method}

A questionnaire was used for gathering data concerning head teachers' influence on instructional supervision practices on teachers' performances (teaching/learning process in their work environment) and also to get teachers' perceptions and feelings of the head teachers visits into their classes. The questionnaire was divided into 5 sections, with section one containing items on respondents' demographic characteristics such as sex, age, name of institution, duration as head teacher, professional experience and educational qualification for head teachers and teachers. The other sections contained items pertaining to teachers' and head teachers' perceptions of classroom 
visits and checking of teachers' work records by head teachers.

A total of 24 items were grouped by constructs to represents the goals of the study: head teachers' instructional supervision practices; limited to two supervision practices: classroom visitations and checking of teaching records (log-books) by head teachers. The demographic constructs asked respondents' basic characteristics such as gender, age, longevity in service, and educational qualifications. Apart from section one which contained demographic items, the response options for all the other items on the questionnaire consisted of a four-point likert scale: Strongly Agree (SA), Agree (A), Disagree (D), and Strongly Disagree (SD). The items were pilot tested with 3 teachers and one head teacher for clarity and restructuring.

Contact visits to meet with head teachers and teachers to explain to them the purpose of the study and seek consent were made. The questionnaire was administered by taking them to the institutions and explaining to the respondents. Each respondent was required to fill out the information in the questionnaire and they were collected after completion. Issues of confidentiality were raised and discussed with participants. The data was coded and analyzed using Statistical Package for Social Sciences (SPSS) V.20.0. Quantitative data derived from the demographic section of the questionnaires from close-ended questions was analyzed using descriptive statistics that included the use of frequencies and percentages.

\subsection{Demographics of Participants}

Twenty-eight teachers and 6 head teachers of the six selected primary schools filled out two different questionnaires: one for the 6 head-teachers and another for the 28 teachers, involving a total of 34 participants in the study. Table 2 below shows demographic characteristics of the 28 teachers and 06 head teachers who participated in the study.

Table 2: Demographic Characteristics of Study Participants

\begin{tabular}{|c|c|c|c|c|c|}
\hline \multirow[t]{2}{*}{ Characteristic } & \multirow[t]{2}{*}{ Category } & \multicolumn{2}{|c|}{ Frequency } & \multicolumn{2}{|c|}{ Percentages (\%) } \\
\hline & & Teachers & Head Teachers & Teachers & Head Teachers \\
\hline & Male & 7 & 1 & 25.0 & 16.7 \\
\hline \multirow[t]{4}{*}{ Gender } & Female & 21 & 5 & 75.0 & 83.3 \\
\hline & Total & 28 & 6 & 100 & 100 \\
\hline & $21-30$ years & 12 & 2 & 42.9 & 33.3 \\
\hline & $31-40$ years & 10 & 3 & 35.7 & 50 \\
\hline \multirow[t]{5}{*}{ Age } & $41-50$ years & 5 & 1 & 17.9 & 16.7 \\
\hline & Over 50 years & 1 & 0 & 3.6 & 00 \\
\hline & Total & 28 & 6 & 100 & 100 \\
\hline & $1-5$ years & 15 & 2 & 53.6 & 33.3 \\
\hline & $6-10$ years & 10 & 2 & 35.7 & 33.3 \\
\hline \multirow[t]{5}{*}{ Longevity } & $11-15$ years & 2 & 1 & 7.1 & 16.7 \\
\hline & Over 16 years & 1 & 1 & 3.6 & 167 \\
\hline & Total & 28 & 6 & 100 & 100 \\
\hline & M.ED & 1 & 1 & 3.6 & 16.7 \\
\hline & B.ED & 4 & 2 & 14.3 & 33.3 \\
\hline \multirow[t]{3}{*}{ Qualification } & CAPIEMP & 18 & 3 & 64.3 & 50 \\
\hline & Others & 5 & 0 & 17.9 & 00 \\
\hline & Total & 28 & 06 & 100 & 100 \\
\hline
\end{tabular}

As shown in Table 2, of the 28 teachers and 6 head teachers who participated in the study, 7 (25\%) of the teachers and $1(16.7 \%)$ of the head teachers were males, while $21(75 \%)$ of the teachers and $5(83.3 \%)$ head teachers were females respectively. Also, $12(42.9 \%)$ of these teachers and $2(33.3 \%)$ of the head teachers fall between the age range of $21-30$ years old, $10(35.7 \%)$ of the teachers and $3(50 \%)$ of the head teachers were between the age range of $31-40$ years, $5(17.9 \%)$ of teachers and $1(16.7 \%)$ head teacher were between the age range of $41-50$ years and $1(3.6 \%)$ teacher was in the age range of over 50 years old. Among the participants, $15(53.6 \%)$ teachers 
and $2(33.3 \%)$ head teachers had 1 to 5 years of experience in Konye Sub-Division, 10 (35.7\%) teachers and $2(33.3 \%)$ head teachers had 6 to 10 years, $2(7.1 \%)$ of teachers and $1(16.7 \%)$ head teacher had 11 to 15 years and $1(3.6 \%)$ teacher and $1(16.7 \%)$ head teacher had over 16 years of longevity respectively in the Konye Sub-Division. It means that teachers in the area are relatively new in the profession. Moreover, of the respondents, $1(3.6 \%)$ teacher and $1(16.7 \%)$ head teacher had a Masters in Education (M.ED), 4 (14.3\%) teachers and 2 (33.3\%) head teachers had a Bachelors in Education (B.ED), $18(64.3 \%)$ teachers and $3(50 \%)$ head teachers had a CAPIEMP and $5(17.9 \%)$ of teachers had other unspecified certificates.

\section{Findings and Discussions}

To determine the influence of head teachers' instructional supervision practices on teachers' performances, teachers were asked to indicate their perceptions of head teachers' classroom visits on their teaching/learning performances as presented on the survey items on Table 3 . The results revealed that more than half of the teachers (64.3\%) strongly agreed and agreed that head teachers occasionally visits learning sessions in classroom, while (35.7\%) disagreed. During supervision visits by head teachers, many teachers $(75.0 \%)$ strongly agreed and agreed that head teachers checked the pupils' assignment and continuous assignment papers to ensure corrections are effected regularly; whereas (25\%) of teachers indicated they disagree. Moreover, $(71.4 \%)$ of teachers noted that head teachers examined the teaching/learning methods which they used in their classrooms, while (28.6\%) disagreed and strongly disagreed.

Table 3: Teachers' Responses on the Impact of Head Teachers' Classrooms Visit on Teachers' Performances in Konye Sub-Division

\begin{tabular}{|c|c|c|c|c|c|}
\hline Item & $\begin{array}{l}\text { Strongly } \\
\text { Agree }\end{array}$ & Agree & Disagree & $\begin{array}{l}\text { Strongly } \\
\text { Disagree }\end{array}$ & Total \\
\hline The head teachers visits learning sessions in Classroom & $11(39.3 \%)$ & $7(25 \%)$ & $7(25 \%)$ & $3(10.7 \%)$ & $\begin{array}{c}28 \\
(100 \%)\end{array}$ \\
\hline TOTAL & \multicolumn{2}{|c|}{$64.3 \%$} & \multicolumn{2}{|c|}{$35.7 \%$} & $100 \%$ \\
\hline $\begin{array}{l}\text { The head teacher checks on pupil's assignment and } \\
\text { continuous assessment scripts to ensure regular } \\
\text { corrections takes place. }\end{array}$ & $5(17.9 \%)$ & $\begin{array}{c}16 \\
(57.1 \%)\end{array}$ & $7(25 \%)$ & $0(00 \%)$ & $\begin{array}{c}28 \\
(100 \%)\end{array}$ \\
\hline TOTAL & \multicolumn{2}{|c|}{$75.0 \%$} & \multicolumn{2}{|c|}{$25 \%$} & $100 \%$ \\
\hline $\begin{array}{l}\text { The head teacher examines the teaching/learning } \\
\text { methods used by the teacher in the classroom }\end{array}$ & $11(39.2 \%)$ & $9(32.1 \%)$ & $\begin{array}{c}5 \\
(17.9 \%)\end{array}$ & $3(10.7 \%)$ & $\begin{array}{c}28 \\
(100 \%)\end{array}$ \\
\hline TOTAL & \multicolumn{2}{|c|}{$71.4 \%$} & \multicolumn{2}{|c|}{$28.6 \%$} & $100 \%$ \\
\hline $\begin{array}{l}\text { The head teacher observes my teaching when he visits } \\
\text { my class. }\end{array}$ & $8(28.6 \%)$ & $\begin{array}{c}15 \\
(53.6 \%)\end{array}$ & $\begin{array}{c}3 \\
(10.7 \%)\end{array}$ & $2(7.1 \%)$ & $\begin{array}{c}28 \\
(100 \%)\end{array}$ \\
\hline TOTAL & \multicolumn{2}{|c|}{$82.2 \%$} & \multicolumn{2}{|c|}{$17.8 \%$} & $100 \%$ \\
\hline $\begin{array}{l}\text { Classroom visitation by head teacher helps to enhance } \\
\text { my teaching. }\end{array}$ & $8(28.6 \%)$ & $14(50 \%)$ & $\begin{array}{l}3 \\
(10.7 \%)\end{array}$ & $3(10.7 \%)$ & $\begin{array}{c}28 \\
(100 \%)\end{array}$ \\
\hline TOTAL & \multicolumn{2}{|c|}{$78.6 \%$} & \multicolumn{2}{|c|}{$21.4 \%$} & $100 \%$ \\
\hline
\end{tabular}

Majority of the teachers $(82.2 \%)$ strongly agreed and agreed that head teachers observed their teaching lessons during classroom visits, while (17.8\%) disagreed and strongly disagreed. Finally, $(78.6 \%)$ of the teachers strongly agreed and agreed that head teachers' classroom visits help to enhance their teaching while $(21.4 \%)$ disagreed and strongly disagreed that classroom visits enhance their teaching process.

In order to examine the influence of head teachers' instructional supervision practices on teachers' performance, the study looked at how frequent head teachers' classroom visits influences teachers' performance. The next set of items had to do with head teachers' perceptions of the impact of their classroom visits on teachers' performances. The same items were readjusted to target head teachers perceptions. Majority of the head teachers $(83.3 \%)$ strongly agreed and agreed that they visits learning sessions in classrooms, while $(16.7 \%)$ disagreed. Moreover, half the population of head teachers who visit classroom learning sessions (50\%) strongly agreed and agreed that they check pupils' assignments and continuous assessment papers to ensure regular corrections take place during their classroom visits; whereas another half $(50 \%)$ of head teachers 
do not check pupils' assessment papers or books during their visits.

Table 4: Head Teachers' response on the impact of head teachers' classroom visit on Teachers' performances in Konye Sub-Division.

\begin{tabular}{|c|c|c|c|c|c|}
\hline Item & Strongly Agree & Agree & Disagree & Strongly Disagree & Total \\
\hline $\begin{array}{l}\text { I visit teachers learning sessions in the } \\
\text { Classroom. }\end{array}$ & $2(33.3 \%)$ & $3(50 \%)$ & $1(16.7 \%)$ & $0(00 \%)$ & $6(100 \%)$ \\
\hline TOTAL & $83.3 \%$ & & & $16.7 \%$ & $100 \%$ \\
\hline $\begin{array}{l}\text { I do take out time to check on pupil's } \\
\text { assignment and continuous assessment scripts } \\
\text { to ensure regular corrections take place. }\end{array}$ & $2(33.3 \%)$ & $1(16.7 \%)$ & $3(50 \%)$ & $0(00 \%)$ & $6(100 \%)$ \\
\hline TOTAL & $50 \%$ & & & $50 \%$ & $100 \%$ \\
\hline $\begin{array}{l}\text { I examines the teaching/ learning aids used by } \\
\text { the teacher in the classroom }\end{array}$ & $2(33.3 \%)$ & $2(33.3 \%)$ & $2(33.3 \%)$ & $0(00 \%)$ & $6(100 \%)$ \\
\hline TOTAL & $66.6 \%$ & & & $33.4 \%$ & $100 \%$ \\
\hline $\begin{array}{l}\text { I do observe my teachers teaching when I visit } \\
\text { them in class. }\end{array}$ & $1(33.3 \%)$ & $3(50 \%)$ & $2(16.7 \%)$ & $0(00 \%)$ & $6(100 \%)$ \\
\hline TOTAL & $83.3 \%$ & & & $16.7 \%$ & $100 \%$ \\
\hline $\begin{array}{l}\text { Classroom visitation by head teacher helps to } \\
\text { enhance teaching and monitoring the } \\
\text { teaching/learning process. }\end{array}$ & $2(33.3 \%)$ & $2(33.3 \%)$ & $1(16.7 \%)$ & $1(16.7 \%)$ & $6(100 \%)$ \\
\hline TOTAL & $66.6 \%$ & & & $33.4 \%$ & $100 \%$ \\
\hline
\end{tabular}

More than half $(66.6 \%)$ of head teachers noted that head teachers examined the teaching/learning aids used by teachers in their classrooms, while (33.4\%) are disagreed. Majority of the head teachers $(83.3 \%)$ strongly agreed and agreed that they observed teachers teach during their classroom visits, while $(16.3 \%)$ disagreed. More than half $(66.6 \%)$ of head teachers' strongly agreed and agreed that their classroom visits and observation help teachers to enhance their teaching process; whereas $33.4 \%$ disagreed.

Table 5: Teachers' responses on checking of records by head teachers and its impact on teachers' performances in Konye Sub-Division

\begin{tabular}{|c|c|c|c|c|c|}
\hline Item & Strongly Agree & Agree & Disagree & Strongly Disagree & Total \\
\hline $\begin{array}{l}\text { The head teacher monitors the preparation } \\
\text { of school timetable }\end{array}$ & $14(50 \%)$ & $10(35.7 \%)$ & $3(10.7 \%)$ & $1(3.6 \%)$ & $28(100 \%)$ \\
\hline TOTAL & \multicolumn{2}{|c|}{$84.7 \%$} & \multicolumn{2}{|r|}{$14.3 \%$} & $100 \%$ \\
\hline $\begin{array}{l}\text { The head teacher checks on records of } \\
\text { work covered }\end{array}$ & $19(67.9 \%)$ & $7(25 \%)$ & $1(3.55 \%)$ & $1(3.55 \%)$ & $28(100 \%)$ \\
\hline TOTAL & \multicolumn{2}{|c|}{$92.9 \%$} & \multicolumn{2}{|r|}{$7.1 \%$} & $100 \%$ \\
\hline $\begin{array}{l}\text { The head teacher checks and corrects } \\
\text { teachers' lesson notes. }\end{array}$ & $21(85.7 \%)$ & $1(3.6 \%)$ & $1(3.6 \%)$ & $2(7.1 \%)$ & $28(100 \%)$ \\
\hline TOTAL & \multicolumn{2}{|c|}{$89.3 \%$} & \multicolumn{2}{|r|}{$10.7 \%$} & $100 \%$ \\
\hline $\begin{array}{l}\text { The head teacher observes and corrects } \\
\text { teacher's lesson plan. }\end{array}$ & $18(64.2 \%)$ & $6(21.4 \%)$ & $1(3.6 \%)$ & $3(10.7 \%)$ & $28(100 \%)$ \\
\hline $\begin{array}{l}\text { TOTAL } \\
\text { The head teacher holds sessions with } \\
\text { teachers and guides them on lesson notes } \\
\text { writing. }\end{array}$ & $\begin{array}{l}\mathbf{8 5 . 7} \% \\
13(46.4 \%)\end{array}$ & $10(35.7 \%)$ & \multicolumn{2}{|r|}{$\begin{array}{l}14.3 \% \\
2(7.1 \%)\end{array}$} & $\begin{array}{c}100 \% \\
28(100 \%)\end{array}$ \\
\hline TOTAL & \multicolumn{2}{|l|}{$82.1 \%$} & & $17.9 \%$ & $100 \%$ \\
\hline
\end{tabular}

The last set of items on the questionnaire was asked to get teachers and head teachers' perceptions on whether checking of records by head teachers influence on teachers' performances in teaching/learning process. Table 5 , shows various frequencies and percentages on the effect of checking of work records by head teachers on teachers' performances in Konye Sub-Division. The results show that majority $(84.7 \%)$ of teachers strongly agreed and agreed that head teachers monitors the preparation of school timetable, while (14.3\%) disagreed and strongly disagreed. A large majority of teachers $(92.9 \%)$ strongly agreed and agreed that head teachers checked records of work covered, while $(7.1 \%)$ of teachers disagreed. Majority of the teachers $(85.7 \%)$ strongly agreed and agreed that head teachers not only checks and corrects teachers lesson plans and 
notes but they also observe how it is being used in class; whereas (14.3\%) disagreed and strongly disagreed. When it concerns head teachers hold sessions with teachers and guides them on lesson notes writing, many teachers $(82.1 \%)$ responded positively - strongly agreed and agreed, while others $(17.9 \%)$ disagreed and strongly disagreed.

The final section of the instrument was made up of items to get perceptions of head-teachers on whether checking of teachers' records by them has an impact on teachers' work performances. The same set of items that were asked for teachers were re-adjusted to also get head teachers' perceptions.

Table 6. Head-Teachers' response on checking of records by head teachers and its impact on teachers' performances in Konye Sub-Division

\begin{tabular}{|c|c|c|c|c|c|}
\hline Item & Strongly Agree & Agree & Disagree & Strongly Disagree & Total \\
\hline $\begin{array}{l}\text { I monitor the preparation of school } \\
\text { timetable }\end{array}$ & $2(33.3 \%)$ & $2(33.3 \%)$ & $1(16.7 \%)$ & $1(16.7 \%)$ & $6(100 \%)$ \\
\hline TOTAL & $66.6 \%$ & & & $33.4 \%$ & $100 \%$ \\
\hline $\begin{array}{l}\text { I regularly check on record booklets to find } \\
\text { out the amount of work covered. }\end{array}$ & $4(66.6 \%)$ & $1(16.7 \%)$ & $1(16.7 \%)$ & $0(00 \%)$ & $6(100 \%)$ \\
\hline TOTAL & $83.3 \%$ & & & $16.7 \%$ & $100 \%$ \\
\hline $\begin{array}{l}\text { I do check and corrects teachers' lesson } \\
\text { notes and plans. }\end{array}$ & $4(66.6 \%)$ & $2(33.4 \%)$ & $0(00 \%)$ & $0(00 \%)$ & 6( \\
\hline $\begin{array}{l}\text { TOTAL } \\
\text { The head teacher holds sessions with } \\
\text { teachers and guides them on lesson notes } \\
\text { writing. }\end{array}$ & $2(33.3 \%)$ & $2(33.3 \%)$ & $2(33.3 \%)$ & $\begin{array}{l}\mathbf{0 0 \%} \\
\quad 0(00 \%)\end{array}$ & $\begin{array}{c}100 \% \\
6(100 \%)\end{array}$ \\
\hline $\begin{array}{l}\text { TOTAL } \\
\text { The checking of records aid in the provision } \\
\text { of feedback to teachers and has an } \\
\text { influence on their performance. }\end{array}$ & $\begin{array}{l}\mathbf{6 6 . 6 \%} \\
3(50 \%)\end{array}$ & $2(33.3 \%)$ & $0(00 \%)$ & $\begin{array}{l}33.3 \% \\
1(16.7 \%)\end{array}$ & $\begin{array}{c}100 \% \\
6(100 \%)\end{array}$ \\
\hline TOTAL & $83.3 \%$ & & & $16.7 \%$ & $100 \%$ \\
\hline
\end{tabular}

As presented on Table 6 , the results revealed that most of the head teachers $(66.6 \%)$ considered that head teachers' monitors the preparation of school timetable, while $(33.4 \%)$ disagreed or strongly disagreed. Majority of the head teachers (83.3\%) strongly agreed and agreed that they regularly check teachers' records books, while $(16.7 \%)$ disagreed. All head-teachers who participated in the study (100\%) strongly agreed and agreed that they check and correct teachers' lesson plans and teaching notes. Asked if head teachers hold sessions with teachers and guides them on writing lesson notes, $(66.6 \%)$ of teachers responded positively by strongly agreeing; while $(33.4 \%)$ disagreed. Finally, majority of head-teachers (83.3\%) strongly agreed and agreed that checking of teaching records helps in providing feedback to teachers to improve on their teaching/learning methods; while $16.7 \%$ strongly disagreed.

\section{Discussion of Findings}

Participants of the study, both teachers and head teachers strongly agreed $(78.6 \%$ and $66.6 \%)$ that head teachers' classroom visits help enhance teaching. Findings of the study further revealed that important aspects that influence teachers' performances during instructional supervision by head teachers were the observation of teaching by head teachers $(82.2 \%$ and $83.3 \%)$ and the examination of the teaching/learning methods used by teachers during supervision $(71.4 \%$ and $66.6 \%$ ). Therefore, by visiting learning sessions, observing teachers teaching, and examining the teaching/learning methods used by teachers, head teachers' supervision practices positively influence and enhance teachers' work performances.

As the frequencies and percentages indicated, teachers and head teachers highly perceive the checking of records by head teachers has having a positive influence on teachers' work performances. These results indicate that head teachers who participated in this study regularly checks and corrects teachers' lesson plans and notes $(89.3 \%$ and $100 \%)$, regular checking records of work covered by teachers $(92.9 \%$ and $83.3 \%)$ and conducting a number of activities such as: monitoring the preparation of school timetable ( $84.7 \%$ and $66.6 \%)$; observes and corrects teachers' 
lesson plan (85.7\% and $100 \%)$; and holding sessions with teachers to guides them on writing lesson. Classroom visits by head teachers, enables monitoring of classroom activities such as: checking class records, guides teaching and enables intervention which can positively influence teachers work performances. With such instructional supervision activities by the head teachers, many teachers such as student-teachers in training, newly recruited teachers and untrained teachers who may not have sufficient mastery of or acquire skills for effective teaching-learning get valuable feedback to improve their teaching-learning performances and professional growth (De Grauwe, 2007).

\section{Concluding Remarks and Recommendations}

Several studies have found supervision to be of value in improving teaching-learning. The findings of this study also prove to be the same with that of other studies (Nolan, 2004; Habimana, 2008; Gongera, 2013) which states that the ultimate aim of supervision is improving on instruction for providing better education. When head teachers frequently monitors the performances of primary school teachers, noting the merit and demerit using benefiting and suitable techniques, it leads to high success rates amongst primary school pupils in national examinations in basic education in Konye Sub-Division in Cameroon. Furthermore, due to adequate instructional supervision practices such as regular classroom visits ensure that head teachers observed and act on students discipline, know the teaching learning methods used in teaching and checking teachers' log-books and the use of feedback influence positively teachers' work performances.

Conclusion is drawn from the findings of this study that head teachers' instructional supervision practices impacts teachers' performances positively in Konye Sub-Division through classroom visits and checking of records during instructional supervision by head teachers. It would be realized that if these practices are carried out regularly by head teachers, teachers' work performances will be enhanced and the teaching-learning process will be ameliorated and yield high pupils' success rates in Konye Sub-Division.

Drawn from the findings of this study, the researcher suggests three basic but important recommendations to increase academic performance and quality in primary schools in remote areas in Cameroon:

1. Basic education teachers with many years of experiences in the profession be transferred to remote areas as head teachers in primary schools.

2. Basic education teachers should be encouraged to take up degree programmes in the university through distance education programmes to earn certificates for career advancement in addition to their professional diplomas in teaching at nursery and primary level (CAPIEMP).

3. More research should be done on other strategies used by head teachers to improve performance in primary schools in remote areas of the country, including the availability of teaching and research resources to teachers of basic education.

\section{References}

Acheson, K. A., \& Gall, M. D. (1987). Techniques in the Clinical Supervision of Teachers: Pre-Service and InService Applications. New York: Longman Publishers.

Archibong, F. I. (2012). Instructional Supervision in the Administration of Secondary Education: A Panacea of Quality Assurance: EJGE, Vol. 17, $1793-1800$.

Blasé, J., \& Blasé, J. (1999). Principals instructional leadership and development: Teachers perspectives. Educational Administration Quarterly, 35, 349 - 378.

Brandt, N.O. (2007). Instructional leadership for quality learning: An assessment of the impact of the primary school management development project in Botswana. Educational Management, Administration and Leadership, 36(4), 471-494 Doi: 10.1177/1741143208095789

De Grauwe, A. (2007). Transforming school supervision into a tool for quality improvement. International Review of Education, 53 (5-6), 709-714.

Divisional Delegation of Basic Education, (2016). End of year report. Meme, Kumba: Local Print.

Douglass, H. R., \& Bent, R. K. (1953). Supervision in schools. cambrige, Massachusetts: The Riverside Press. 
Fokeng, E. G. (2010). The history of education in Cameroon, 1844-2004. New York: Edwin Mecler Press.

Frazer, K. (2001). Supervisory behaviour and teacher satisfaction. Journal of Educational Administration 18(2) $P$ $224-227$.

Gerumi , S. (2003). Instructional Supervision: its impact on Teachers' and Students' Performance. Unpublished Master Thesis, University of Nueva Caceres, Naga City.

Glatthorn, A. A. (2007). Co-operative professional development peer centred options for teacher growth. New York: Educational Leadership.

Glickman, C. D; Gordon, S. P., \& Ross, C. (1998). Supervision of Instruction: A Developmental Approach. (4 ${ }^{\text {th }}$ ed.).Boston, MA: Allyn \& Bacon.

Gongera, Y. I. (2013). School principal's roles in teaching supervision in selected schools in Perak, Malaysia. Asian Journal of Business and Management Sciences, 50-55

Habimana, A. M. (2008). The effect of head teachers' instructional supervisory practices on performance of private secondary school students in Musanze District, Rwanda. Unpublished Master's Thesis, Bugema University.

Kerubo, M. J. (2010). Role of head teachers' instructional supervision on Kenya's certificate of primary education performance in public primary schools, Dagoretti District, Kenya.

Marecho, H. (2012). Challenges facing instructional supervision in public primary schools in Nyamira District. Kenya.

Mgbodille, M. G. (1996). Head teachers' characteristics influencing instructional supervision in public primary schools in Kasarani District, Kenya. Unpublished Master's Thesis, University of Nairobi, Nairobi, Kenya.

Ministry of Basic Education. (2005). Draft document of the sector wide approach to education. Yaounde, Local Print.

Ministry of Basic Education. (2012). Framework of basic education road map. Yaounde: Local Print.

Mohammed, T. (2014). Effects of educational supervision on students' academic performance in Nadowli District in the Upper West Region of Ghana. The International Journal of Humanities \& Social Studies, 2(6), 326-341.

Mohanty, J. (2008). Educational administration supervision and school management. New Delhi: Deep \& Deep Publications.

Musungu, L. L., \& Nasongo, J.W. (2008). The head teacher's instructional role in academic achievement in secondary schools in Vihiga District, Kenya. Educational Research and Review, 3 (10), 316 - 328.

Nolan, J., \& Hoover, L. (2004).Teacher Supervision and Evaluation: Theory into Practice. Hoboken, NJ: John Wiley \& Sons, Inc.

Panigrahi, M. R. (2012). Implementation of instructional supervision in planning and supervision in secondary schools: Approaches, prospects and problems. Science, Technology \& Arts Research Journal, 1 (3), 5657.

Sergiovanni, T. J., \& Starratt, R. J. (2002). Supervision: A redefinition (7th ed.). Boston, MA: McGraw-Hill.

Southworth, G. (2002). Instructional leadership in Schools: Reflections and Empirical Evidence. School Leadership and Management, 22 (1), 73-91

Sullivan, S., \& Glanz, J. (2000a). Alternative approaches to supervision: Cases from the field. Journal of Curriculum and Supervision, 15(3), 212-235.

Sullivan, S., \& Glanz, J. (2000b).Supervision that improves teaching: Strategies and techniques. Thousand Oaks, CA: Corwin Press, Inc.

Tambo, L. (2003). The Cameroon National Education Policy since the 1995 Forum. Limbe, Design House.

Tambo, L. I. (2000). The national education forum of 1995. In T. M. Ndongko \& L. I. Tambo's (Eds.), Educational developments in Cameroon (1961-1999). Platteville, WA, Nkemnji Global Tech.

Thakral, S. (2015). The historical context of modern concept of supervision. Journal of Emerging Trends in Educational Research and Policy Studies, 6(1), 79-88.

Tshabalala, T. (2013). Teachers' perceptions towards classroom instructional supervision: A case study of Nkayi District in Zimbabwe. International Journal of Social Science \& Education, 4(1), 25-32.

Wambui, K. M. (2015). Influence of head teachers' instructional supervision practices on pupils' performance in Kenya certificate of primary education in Kiambu sub county, Kenya. Unpublished Master's Thesis, University of Nairobi, Nairobi: Kenya.

Wiles, J., \& Bondi, J. (1996). Supervision: A guide to practice ( $4^{\text {th }}$ ed.). Englewood Cliffs, NJ: Merrill.

Wiles, J., \& Bondi, J. (2002).Curriculum Development: A Guide to Practice $\left(6^{\text {th }}\right.$ ed.). Upper Saddle River, NJ: Merrill Prentice Hall.

Zepeda, S. J. (2007). Instructional Supervision Applying Tools and Concepts. Larchmont, NY: Eye on Education. 